\title{
What do Depositors Know about Risk?
}

\author{
Caner Selçuk* ${ }^{*}$ Özyıldırım Süheyla ${ }^{* *}$, Ungan Ayse Ece ${ }^{* * *}$ \\ * International Monetary Fund, 700 19th Street, N.W., Washington, D.C. 20431, USA. \\ E-mail: scaner@imf.org \\ ** Faculty of Business Administration, Bilkent University, Ankara, 06800, Turkey. \\ E-mail: suheyla@bilkent.edu.tr \\ *** Alternatifbank A.Ş, 46, Cumhuriyet Caddesi, Elmadağ - Şişli, Istanbul, Turkey. \\ E-mail: ece.ungan@abank.com.tr
}

The limited success of bank supervision can be better understood by taking into consideration the country conditions and market-based measures that are effective in constraining bank risk. In the case of Russian Federation and Turkey, regulators' incentive to oversight can be further complicated and hence, it can be argued that depositors compel to select sound banks if they continue to fund intermediation by banks in two countries. In this paper, depositors' sensitivity to risk using change in deposits and the level of interest rates on deposits are tested to understand whether they can effectively limit risk-taking behavior of banks. Comparing depositors' reaction in two countries, we find differentiated reaction by depositors to bank risks. In the Russian Federation, it seems that depositors respond weakly to increased bank risks only with the possibility of withdrawing funds. However, in Turkey depositors exercise both quantity and price discipline on the banks which facilitates in identifying risky banks. Moreover, market development, effectiveness of supervisory agencies, types of banks and types of depositors are found to affect depositors' reaction against banks. The findings of this study suggest that the experiences of depositors in both countries seem to play important role in reliance to market discipline in the future.

Key words: bank risk; monitoring; large depositors; market discipline.

JEL Classification: G21; G32.

\section{Introduction}

Although it has not made the headlines to the scale of England or Ireland one of the biggest banking industry restructuring exercises took place in the Russian Federation in the aftermath of the financial crisis. This occurred despite continued efforts of the Central Bank of Russia (CBR) to clean up the Russian banking system since 2000. The Central Bank of Russia took a three pronged approach to avoid a bank run similar to the one in 1998 and mitigate the 
effects of the crisis on the rest of the economy. First, starting in 2008, 123 banks were liquidated and their licenses revoked. An additional 28 banks were merged with other banks or reorganized bringing the total number of liquidated banks to 151 by $2010^{1}$. The total cost of liquidating banks was 22,7 billion rubles all paid by the Deposit Insurance Agency (DIA) (2009). The second course of action was to recapitalize 14 banks at a cost of 328 billion rubles all in the form of Central Bank and Federal Budget Credits [DIA, 2009; Turbanov, 2010].This amount is to be paid back by the banks over five years. The third set of measures was to extend credit to sound banks to the amount of 4223,7 billion rubles [CBR, 2010]. Two state banks, Sberbank and Vneshtorgbank played key roles in selecting banks and distributing the refinancing credits provided by the CBR.

The Russian banking system weathered the crisis but the costs were significant. However during the same period, the banking system of another country was not affected by the global financial crisis despite its recent experiences in several banking crises ${ }^{2}$. The Turkish banking industry was not affected by the global crisis even though the economy activity declined significantly in 2009, i.e., GDP declined by $9 \%$ in 2009 . The two countries, despite the similarities in banking industry, have managed their risks in a completely different manner. We argue that one of the main factors that explain the difference in the management of bank risks is the market discipline exercised in both countries by the depositors. In the Russian Federation, depositors are found to weakly respond to increased bank risks only with the possibility of withdrawing funds. However, in Turkey depositors exercise both quantity and price discipline on the banks which facilitates in identifying risky banks.

The use of market discipline for prudential purposes has gained importance in recent years as policymakers have increasingly recognized its role and incorporated it in their regulatory frameworks. The most important mechanism to facilitate market discipline is thought to be disclosure of accurate information to the market, and the market's ability to process it properly. Of course, market discipline works if market participants have sufficient incentives to fulfill their monitoring role and there are no impediments to information signals. A major problem with the prudential regulators is an agency problem as observed as a precursor of the financial crisis in 2008. The regulators appear to have been rather poor agents for their healthy bank and taxpayer principals ${ }^{3}$. Recently, Kaufman (2010) argued that regulators failed to enforce either the letter or the spirit of the rules that were on the books during the crisis period of 2007-2009. They feared of serious and costly bank failures and financial meltdowns on their watch that would have damaged their reputations. As a result, last global financial crisis has exposed important limitations of market discipline and has cast doubts on its effectiveness as a prudential mechanism.

In the literature, there is evidence that depositor reaction can be exercised through both withdrawal of deposits and demanding appropriate risk premiums. For example, Park and Pe-

\footnotetext{
1 The effort of CBR is no less than the efforts taken by the Federal Reserve.

2 Turkey had one major banking crisis in 1994 and another one as recently as 2001.

${ }^{3}$ A good example is the case of Bank Moskovy which made the headlines in July 2011. Bank Moskovy was owned by the City of Moscow and private shareholders including investment banks such as Goldman Sachs and Credit Suisse. The bank was acquired by Vhenshtorgbank (VTB) early in 2011. After the acquisition was completed, it was discovered that Bank Moskovy had 14 billion dollar in losses from loans to mostly off-shore companies related to the management of the bank and former City of Moscow officials. This questions the supervisory ability of the Moscow branch of the Central Bank of Russia (CBR) which was supposed to be the best among all the regions.
} 
ristiani (1998) and Goldberg and Hudgins (1996) find evidence of depositors' discipline in U.S. thrifts and Savings and Loans Associations, respectively. Maechler and McDill (2006) also examine US banks and show that when a bank's fundamentals are deteriorating, both the price and quantity of uninsured deposits shift simultaneously suggesting depositor discipline. Birchler and Maechler (2002) document that in Switzerland depositors respond to institutional changes in the Swiss depositor protection system and behave differently across different types of banks with different implicit insurance levels.

There is also evidence from developing countries. During the Mexican tequila crisis, using daily deposit data for a sample of 120 banks, over a four-month period around the bank panic in Argentina, D'Amato, Grubisic and Powell (1997) show that the amount of deposits lost is explained by bank fundamentals, macroeconomic factors or «contagion». Similarly, Calomiris and Powell (2001) show that depositors withdrew one-fifth of the deposit base during the same crisis in Argentina which expedited weak banks to close and disciplined the surviving ones. They argue that this process made Argentina's banking system resilient during the Asian, Russian, and Brazilian crises. Using data for Argentina, Chile, and Mexico, Martinez Peria and Schmukler (2001) find that depositors withdraw their deposits and ask higher interest rates from weak banks. Their evidence is robust for both small and large depositors. Moreover, Barajas and Steiner (2000) provide evidence for Colombia; Davies and Robitaille (1997) for Chile; Mondschean and Opiela (1999) for Poland; Opiela (2004) for Thailand; Ungan, Caner, and Ozyildirim (2008) for the Russian Federation.

In this paper, we assess the reaction of depositors in the Russian Federation and Turkey against risk-taking behavior of banks in an environment where bank supervision was not fully developed as an effective institution. In a weak supervisory environment where presence of foreign banks is limited, estimating the influence of risk indicators on depositors' response to bank risk would be more relevant. The findings of the paper suggests that there are some differences in the way depositors react to bank risks in the Russian Federation and Turkey. For example, in the Russian Federation, liquidity and state ownership play a positive role in increasing deposits. In Turkey, banks rely more on deposits to fund credits and can increase the share of loans by paying higher interest rates on deposits. Therefore, depositors are able to price increased risk.

The differences in the results between the two countries can be partly explained by the different experiences of the depositors. In the Russian Federation, depositors were not aware of bank risks until the crisis in 1998. With loss of wealth both in early 1990s and in 1998, Russian depositors' became extremely cautious in placing their savings in the banking system. This is also evident from the persistent low levels of deposits in the banking system. Russian depositors react to increased bank risks by adjusting the level of deposits. In Turkey in addition to reacting to bank risks by changing quantity of deposited funds, depositors are also able to obtain higher interest rates as riskiness of banks increase. Since, Turkey offered full coverage for depositors when it experience financial emergency in 1994, 2000 and 2001, depositors exert discipline by demanding higher deposit rate.

\section{Banking industry in the Russian Federation and Turkey}

In the Russian Federation and Turkey, banks dominate the financial system. As seen from Table 1, the size of the banking sector in both countries is significantly higher than other financial 
institutions. As of 2005 , more than $85 \%$ of the financial assets in both countries were owned by the banking industry. Also, state-owned banks' involvement in financial intermediation is very high in the Russian Federation and Turkey. In Turkey, even though the share of the state-owned banks has declined over the years, the existing three state-owned banks have $31,4 \%$ of the overall banking assets as of 2005 (Table 2). Moreover, state-owned banks account for $24,7 \%$ of the capital and $38,8 \%$ of the deposits of the banking industry while they provide only $21,0 \%$ of the loans. In the Russian Federation, 32 state-owned banks own $40,7 \%$ of the banking industry's assets. State banks account for $33,8 \%$ of the capital and $62 \%$ of the deposits while providing about $46,7 \%$ of loans. Although Russian state-owned banks have a much bigger share of the banking industry than the Turkish banks, the trend in asset share has been converging to the corresponding share in Turkey.

Table 1.

Banking sector assets to non-bank financial institutions' assets as of 2005

\begin{tabular}{l|c|c|c|c|c|c|c|c}
\hline & \multicolumn{3}{c|}{ Russian Federation } & \multicolumn{4}{c}{ Turkey } \\
\cline { 2 - 10 } & $\begin{array}{c}\text { Number of } \\
\text { financial } \\
\text { institution }\end{array}$ & $\begin{array}{c}\text { Assets* } \\
\text { (\$ billion) }\end{array}$ & $\begin{array}{c}\text { Assets to } \\
\text { GDP }\end{array}$ & $\begin{array}{c}\text { Share in } \\
\text { assets }\end{array}$ & $\begin{array}{c}\text { Number of } \\
\text { financial } \\
\text { institution }\end{array}$ & $\begin{array}{c}\text { Assets* } \\
\text { (\$ billion) }\end{array}$ & $\begin{array}{c}\text { Assets to } \\
\text { GDP }\end{array}$ & $\begin{array}{c}\text { Share in } \\
\text { assets }\end{array}$ \\
\hline Banking sector & 1253 & 344,8 & 45,1 & 89,3 & 47 & 294,2 & 81,6 & 85,0 \\
Insurance companies & 1075 & 20,7 & 2,7 & 5,4 & 35 & 6,4 & 1,8 & 1,9 \\
Private pension funds & 261 & 12,2 & 1,6 & 3,2 & 11 & 4,2 & 1,2 & 1,2 \\
Investment funds & 360 & 8,1 & 1,1 & 2,1 & 36 & 23,8 & 6,6 & 6,9 \\
Others** & - & - & - & - & 184 & 17,6 & 4,9 & 5,1 \\
\hline \hline
\end{tabular}

Source: Central Banks of Russia and Banking Regulation and Supervisory Agency of Turkey.

* $1 \$=28,28$ ruble and $1 \$=1,3495$ Turkish lira as of year 2005 .

${ }^{* *}$ Includes participation banks, leasing and factoring companies, securities intermediary institutions and consumer finance companies.

Table 2.

Ownership structure of Russian and Turkish banking sectors, 2005

\begin{tabular}{|c|c|c|c|c|c|c|c|c|c|c|}
\hline & \multicolumn{5}{|c|}{ Russian banking sector } & \multicolumn{5}{|c|}{ Turkish banking sector } \\
\hline & \multirow{2}{*}{$\begin{array}{l}\text { Number } \\
\text { of banks }\end{array}$} & \multicolumn{4}{|c|}{ Share of } & \multirow{2}{*}{$\begin{array}{l}\text { Number of } \\
\text { banks }\end{array}$} & \multicolumn{4}{|c|}{ Share of } \\
\hline & & assets & capital & loans* & deposits & & assets & capital & loans & deposits \\
\hline $\begin{array}{l}\text { State-controlled } \\
\text { banks }\end{array}$ & 32 & 40,7 & 33,8 & 46,7 & 62,0 & 3 & 31,4 & 24,7 & 21,0 & 38,8 \\
\hline Private banks & 1170 & 51,0 & 57,0 & 45,9 & 28,4 & 16 & 59,7 & 55,7 & 65,2 & 57 \\
\hline Foreign banks & 51 & 8,3 & 9,2 & 7,4 & 9,6 & 14 & 5,2 & 6,1 & 9,9 & 4,1 \\
\hline Other banks ${ }^{* *}$ & - & - & - & - & - & 14 & 3,7 & 13,5 & 3,9 & 0,1 \\
\hline Total & 1253 & 100 & 100 & 100 & 100 & 47 & 100 & 100 & 100 & 100 \\
\hline
\end{tabular}

Source: Central Bank of Russia, Banking Regulation and Supervision Agency of Turkey and the Banks Association of Turkey.

${ }^{*}$ Only corporate loans for Russian banks.

** Other banks in Turkey include banks controlled by State Deposit Insurance Fund and Investment and Development banks. 
Foreign banks' share in both countries in terms of assets remains below $10 \%$ which is far from the average in any Central and Eastern European (CEE) banking industry ${ }^{4}$. Overall, banking industry in both countries is characterized by declining share of the state-owned banks and increasing share of private and foreign banks.

CBR classifies domestic private banks as large diversified banks, intra-group banks, that is, banks owned by large corporations, medium and small size Moscow region banks and medium and small regional banks [CBR, 2010]. Diversified banks own about one-fourth of the banking industry's assets and capital. According to CBR, as of 2005, there are 74 diversified banks; 109 inter-group banks; 455 medium and small size Moscow region banks; and 484 medium and small regional banks. The size of the assets of the banks in the Russian Federation varies from $\$ 2$ billion for the largest bank to less than $\$ 10000^{5}$. Often, major depositors of the small banks are the owners, a large firm or local administrations. Hence, the possibility that external depositors may have any influence on bank risk taking in small banks is very unlikely.

Banking industry in the Russian Federation has experienced continuous growth since 2000. Ratio of bank assets to GDP rose from 35,3\% in 2001 to $45 \%$ in 2005 with annual growth of 5\%. Banking sector's asset size as a share of GDP was, on average, 41\% over the period 2000-2005. Despite a severe banking crisis in 2001, asset to GDP ratio in Turkey is almost twice (79\%) as much as in the Russian Federation because of a longer period of asset accumulation in the Turkish banking industry as compared to the Russian Federation.

In the Russian Federation, long-term borrowing and corporate deposits as a source of funding have grown faster than household deposits since 2004 [CBR, 2005]. Diversified banks were able to increase household deposits faster than other groups of banks. These banks also experienced large increases in corporate deposits. Moreover, due to their good international credit ratings, state-owned and diversified banks were able to raise funds in the international interbank market eventually reducing their reliance on deposits. In the Russian Federation, deposits-toassets ratio remains very low at 26\% over the period 2000-2005. On the other hand, banks in Turkey use significant amount of deposits where the deposit asset ratio is $64 \%$ over the sample period. At first sight, depositors' stake at risk is significantly higher in Turkey than in the Russian Federation. As of end of 2005, there are 1,916 million depositors in Turkey with average deposits worth less than 50000 Turkish lira (or \$37000) and fully covered by deposit insurance fund. However, the remaining 708000 deposit account holders with funds over the threshold have reasons to monitor their banks ${ }^{6}$.

Loan portfolios of the banking industry in the Russian Federation have grown faster since 2000. Although demand for commercial credits was strong, the upward trend in loans was partly due to the demand for credit by the households. After 2004, banks were able to increase their borrowed funds especially supplied by money center banks in Europe. The average share of loan portfolio of the banking industry was $49 \%$ of assets during the $2000-2005$ periods. During the same period, Turkish banking sector has been consolidating from two major crises in 2000 and

\footnotetext{
${ }^{4}$ In some CEE countries, almost all banks are owned by foreign banks [Dinger, 2009].

${ }^{5}$ Asset values are based on financial statements in 2005.

6 There are 535000 savers in Turkey with deposits between $\$ 37000$ and $\$ 182000 ; 60000$ savers with deposits between $\$ 182000$ and $\$ 740000$; and 13000 savers with deposits over $\$ 740000$ (or 1 million Turkish lira). As of January 2010, large savers with deposits over 1 million Turkish lira increased to 29000 in Turkey. Unfortunately, we have no comparable figures for the Russian Federation.
} 
2001 and the average share of loan portfolio of the banking industry was $28 \%$. In 2001, bank loans were only $22 \%$ of assets. This ratio increased to $38 \%$ by the end of 2005 . The share of loans in GDP are almost same (around 20\%) over the sample period in both countries.

Another similarity of the banking sector in the Russian Federation and Turkey is the high concentration in the sector. The top 10 banks in Turkey control $83 \%$ of the assets and they provide $78 \%$ of the loans. Moreover $88 \%$ of the deposits is placed in the top 10 banks. However, top 10 banks in Turkey account for $21 \%$ of all banks whereas in the Russian Federation, top 10 banks account for $0,8 \%$ of all banks. In the Russian Federation, the state-owned bank, Sberbank accounts for $28,6 \%$ of all assets and $33 \%$ of total equity in the banking industry. In 2005 , the top ten banks' share in terms of assets in banking industry is $54 \%$ and these banks account for $71 \%$ of the deposits and provide $57 \%$ of the loans of the Russian banking industry.

The performance of banks, in particular the estimated operational efficiency scores ${ }^{7}$ in both countries demonstrate the effects of better use of bank resources. The most efficient banks in the Russian Federation are state-owned banks while privately-owned and foreign banks are most efficient in Turkey. This should not come as a surprise because Russian state-owned banks have undergone major restructuring and consolidation since 2000. Since state-owned banks are already implicitly insured banks, their higher efficiency may undermine depositors' reaction against risk in the Russian Federation. Yet, efficiency scores of the banks in the Russian Federation and Turkey reveal that further improvements are needed for better functioning of the banking system in both countries. Overall the development of the banking industry in each country after respective crises resulted in improved financial intermediation in both countries.

In the case of Russian Federation and Turkey, regulators' incentive to oversight can be further complicated because of possible loss of career, bad reputation, jail time and even loss of life ${ }^{8}$. Given the risks for them for taking prompt corrective actions against weak banks, depositors simply cannot rely on the monitoring and control of bank risks by the supervisors. They have to find ways to select sound banks if they continue to fund intermediation by banks. Hence, in the next section, we estimate the depositors' sensitivity to risk using change in deposits and the level of interest rates on deposits to understand whether they can effectively limit risk-taking behavior of banks.

7 Efficiency scores are calculated using a stochastic production frontier. The input variables used are deposits, equity and labor while the amount of loans was the output.

${ }^{8}$ Evidence on the hazards of bank supervision from the Russian Federation and Turkey illustrate the limitations of supervisory capacity in controlling bank risks. «...Vice Premier Alexander Zhukov said the assassination was likely linked to Kozlov's duties, and suggested the possibility of a connection with the Central Bank's revocation of licenses of unreliable commercial banks, the Interfax news agency reported, according to AP...Kozlov had been responsible for banking supervision, and had overseen an ambitious scheme to reduce criminality and money laundering in the banking system...» (September 14, 2006). A banker later confessed to organizing the murder of Kozlov.

«...ANKARA (AFP) - A Turkish court gave suspended jail sentences yesterday to the former head of the country's banking watchdog and his deputy over a major banking scandal dating back to 2003, the Anatolia news agency reported...Engin Akcakoca, the former chairman of the Banking Regulation and Supervision Board (BDDK), received a one-year suspended sentence for "negligence". His then deputy, Teoman Kerman, received a two-year suspended prison term for abuse of office. They were found guilty of failing to take measures against the private Imar Bank after it was found to be selling non-existent treasury bonds to clients. Five other former BDDK officials were each given one-year suspended jail sentences for negligence» (October 20, 2006). 


\section{Empirical model}

Deposit insurance can be in the form of quantity or price adjustment. To test for any depositor discipline, the following model is estimated to determine the existence of a significant relation between deposits and/or price of deposits and risk indicators of banks. Deposits are expected to adjust their deposits or ask for additional risk premium for their savings at the banks. Moreover,banks are expected to offer the marginal depositor a sufficient rate of return to compensate for risk [Caprio, Honohan, 2005].

We use the following reduced form model to test whether there exists depositors' reaction against bank risk in the Russian Federation and Turkey,

$$
Z_{j, t}^{i}=\alpha_{j}+\sum_{j=1}^{2} \beta_{j} Z_{j, t-1}^{i}+\sum_{k=1}^{5} \varphi_{k} \operatorname{Risk}_{k, t-1}^{i}+\sum_{l=1}^{3} \delta_{l} \text { Bank }_{l, t}^{i}+\sum_{m=1}^{3} \gamma_{m} \text { Dummy }_{m}+\sum_{n=1}^{2} \theta_{n} \text { Macro }_{n, t-1}+u_{t}^{i},
$$

where $u$ is the error term. Depositors' assessment of bank riskiness is measured by the percentage change in the deposits $\left(Z_{1, t}^{i}\right)$ of bank $i$ at time $t$ and by the implicit interest rate paid on deposits $\left(Z_{2, t}^{i}\right)$ by bank $i$ at time $t$. The implicit interest rate is defined as the ratio of deposit interest expense to total deposits in the previous period. The lagged values of the dependent variables are added to the right hand side in order to account for the simultaneity of the growth in deposits and the implicit interest rates. Also, all the risk variables are lagged to avoid any possible endogeneity between the dependent variables and the risk factors.

In all of the monitoring models to discipline banks, the choice of a measure of bank risk plays an important role in understanding the reactions of depositors because depositors can be considered to have no expertise and the means to monitor the bank's management. We assume that depositors take advantage of the provisions of the disclosure statements. In addition, we use the following financial ratios to measure riskiness (Risk) of banks: Non-Performing Loans/ Assets, Total Loans/Assets, Total Capital/Assets, Net Profit After Tax/Assets, Liquid Assets/Assets. Increases both in non-performing loans-to-assets and loans-to-assets affect deposit growth negatively and interest paid on deposits negatively. Increases in capital-to-asset, net after-tax profitto-asset, and liquid assets-to-asset ratios are expected to increase deposits while reducing the interest rate on deposits.

In addition to bank risk indicators, we control various bank characteristics (Bank) that may affect deposit growth and interest rate on deposits. The first set of bank specific variables is: natural logarithm of the assets of the bank and the relative size of the bank's total deposits in the total funding base ${ }^{9}$. In addition, to control for the performance of management, operational efficiency of the banks is introduced. Two dummy variables that differentiate the ownership status of the banks are included to control institutional strategies of banks in the Russian Federation and Turkey. A third dummy variable is introduced to control the effect of full insurance periods in the estimation for Turkish banks. During the period 1997:4-2004:2, all of the household deposits were fully covered by the deposit insurance system in Turkey. Thus, dummy variable for the partial insurance periods (2004:3-2006:3) equals to one otherwise it is zero. Finally, two macroeconomic variables (Macro) are included to the model: changes in the price index and the dollardomestic currency exchange rate.

\footnotetext{
${ }^{9}$ The bank's total funding base includes deposits, interbank loans and long-term debt.
} 


\section{Data}

For the Russian banks, quarterly bank-level data is obtained from data services provider Mobile Information Services for the period 2000:1 to 2005:1. The data for Turkish banking industry is provided by the Banking Association of Turkey and covers the period from 2002:2 to $2006: 3^{10}$. The period of $2000-2005$ is a stable period for the Russian financial markets and the quality of the financial statements are substantially better compared to prior years. In the empirical analysis, we consider only banks with assets greater than $\$ 50$ million because small banks have either very few or no outside depositors. The deposits in such banks are provided by related companies, owners or local administrations. During the period 2000-2005, there are 377 banks in the Russian Federation with asset size greater than $\$ 50$ million. These banks account for about $95 \%$ of the total assets and loans, $96 \%$ of total deposits and $90 \%$ of the total capital of the banking industry [CBR, 2006]. Eleven of the 377 banks are excluded from the data set because of insufficient number of consecutive financial information during the analysis period.

In the estimations for the Turkish banks 41 out of the 47 are used to test the depositors' reaction to bank risk-taking. Six banks were excluded due to insufficient data. Banks included in the estimations account for more than $96 \%$ of the total assets and loans, $99,99 \%$ of total deposits and $87 \%$ of total capital.

Table 3.

Descriptive statistics

\begin{tabular}{|c|c|c|c|c|}
\hline & \multicolumn{2}{|c|}{$\begin{array}{l}\text { Russian banking } \\
\text { industry }\end{array}$} & \multicolumn{2}{|c|}{$\begin{array}{c}\text { Turkish banking } \\
\text { industry }\end{array}$} \\
\hline & mean & standard deviation & mean & standard deviation \\
\hline \multicolumn{5}{|l|}{ Dependent Variable } \\
\hline Growth in Deposits & 0,1665 & 0,6584 & 0,0401 & 0,5262 \\
\hline Implicit Interest Rate & 0,1347 & 1,1563 & 0,2054 & 0,3123 \\
\hline \multicolumn{5}{|l|}{ Bank Riskiness Variables } \\
\hline Non-Performing Loans/Assets & 0,0014 & 0,0072 & 0,0060 & 0,0155 \\
\hline Total Loans/Assets & 0,3580 & 0,1908 & 0,3147 & 0,1836 \\
\hline Total Capital/Assets & 0,2218 & 0,1598 & 0,1690 & 0,1549 \\
\hline Net Profit After Tax/Assets & 0,0222 & 0,0325 & 0,0064 & 0,0794 \\
\hline Liquid Assets/Assets & 0,4423 & 0,2691 & 0,3618 & 0,1900 \\
\hline
\end{tabular}

10 In Turkey, the quarterly data have been available since 1997:4. However, the beginning of the sample period is constrained by the limited financial intermediary role of Turkish commercial before 2002 . Most banks borrowed short-term in international markets and invested the funds in long-term loans to related parties or in government securities to finance government debt requirements during the 1990s [Bredenkamp, Josefsson, Lindgren, 2009]. The industry suffered from chronic macroeconomic instability, crisis, heavy taxation and a weak loan portfolio until 2002. A four-throng comprehensive Banking Sector Restructuring and Rehabilitation Program was started in May 2001 in order to overhaul the banking system aiming to; restructure the state banks, resolve banks taken over by the Savings Deposit Insurance Fund, strengthen the financial structure of private banks and further improve the regulatory and supervisory framework [BDDK, 2010]. 
Continued

\begin{tabular}{l|c|c|c|c}
\hline & \multicolumn{2}{|c|}{$\begin{array}{c}\text { Russian banking } \\
\text { industry }\end{array}$} & \multicolumn{2}{c}{$\begin{array}{c}\text { Turkish banking } \\
\text { industry }\end{array}$} \\
\cline { 2 - 5 } & mean & standard deviation & mean & standard deviation \\
\hline Other Control Variables & & & & \\
Assets (in natural logarithm) & 21,3515 & 1,5612 & 20,8869 & 2,1034 \\
Total Deposits/Total Funding Base & 0,9154 & 0,2106 & 0,6939 & 0,2539 \\
Operational Efficiency & 0,5042 & 0,1812 & 0,5195 & 0,2852 \\
\hline \hline
\end{tabular}

${ }^{*}$ Includes banks with asset size above $\$ 50$ million.

** Starting 2002, Central Bank of Russia introduced new regulations to improve reporting by banks. Since 2004, CBR requires the new methodology to be used in the calculation of capital and liquidity adequacy ratios. Hence, there are slight differences between capitalization and liquidity ratios in both countries.

In Table 3, summary statistics for the dependent and independent variables are presented. On average, banks in both countries are highly capitalized, liquid and utilize deposits as a major source of funds. Moreover, standard deviations of the bank related variables including bank risk measures are very high in both economies. So, the risk characteristics of banks differ significantly. High variance among banks implies that depositors should be able to differentiate among banks based on risk characteristics.

\section{Estimation results}

We run fixed-effects regressions using cross-sectional time series data to estimate the reaction of depositors to bank risks in the Russian Federation and Turkey. Estimated coefficients of the deposit growth and the interest rate equation are reported in Tables 4 .

For all banks in the Russian Federation and in Turkey, we observe that there is a significant slowdown in the deposit growth of banks if the deposit accumulation rate was high in the previous period. Moreover, if banks offered higher interest rates in the previous period, funds deposited in these banks would increase significantly, demonstrating that depositors respond positively to higher interest rates.

We first examine the deposit growth estimates. Leverage measured by loans to asset ratio is negatively related to deposit flows as expected. As observed in columns (1) and (3), increasing loan portfolios increase the credit riskiness of a bank and depositors in both countries withdraw their funds from these banks. Depositors may not follow the riskiness of the loans of a bank but they certainly observe the changes in the economy and develop an idea about the risks of loans under changing economic conditions. The response of depositors to increase in loans in Turkey is bigger than in the Russian Federation. First, this is due to the higher exposure of depositors to risk in Turkey. Deposit asset ratio is twice as much as in the Russian Federation. Second, in the Russian Federation, more than $50 \%$ of deposits are placed in one state-owned bank, Sberbank, which dampens the reaction of the depositors to an increase in asset risk. 
Table 4.

Estimated coefficient

\begin{tabular}{|c|c|c|c|c|}
\hline & \multicolumn{2}{|c|}{ Russian Federation } & \multicolumn{2}{|c|}{ Turkey } \\
\hline & $\begin{array}{l}\text { Growth } \\
\text { in deposits }\end{array}$ & $\begin{array}{c}\text { Implicit } \\
\text { Interest Rate }\end{array}$ & $\begin{array}{c}\text { Growth } \\
\text { in deposits }\end{array}$ & $\begin{array}{c}\text { Implicit } \\
\text { Interest Rate }\end{array}$ \\
\hline & $(1)$ & $(2)$ & (3) & $(4)$ \\
\hline Growth in deposits t-1 $_{1}$ & $\begin{array}{c}-0,2363^{* * *} \\
(-20,0226)\end{array}$ & $\begin{array}{l}-0,1744^{* *} \\
(-9,2987)\end{array}$ & $\begin{array}{l}-0,2169^{* * *} \\
(-5,3768)\end{array}$ & $\begin{array}{l}-0,0384^{*} \\
(1,8593)\end{array}$ \\
\hline Interest Interest Rate $_{t-1}$ & $\begin{array}{l}0,0167^{* *} \\
(2,3766)\end{array}$ & $\begin{array}{c}0,4162^{* *} \\
(37,1419)\end{array}$ & $\begin{array}{c}0,1362^{*} \\
(1,6792)\end{array}$ & $\begin{array}{l}0,3078^{* * *} \\
(7,4651)\end{array}$ \\
\hline \multicolumn{5}{|l|}{ Bank Riskiness $\left(\right.$ Risk $\left._{t-1}\right)$} \\
\hline Non-Performing Loans/Assets & $\begin{array}{c}0,2535 \\
(0,1553)\end{array}$ & $\begin{array}{c}-3,8077 \\
(-1,4633)\end{array}$ & $\begin{array}{c}0,2719 \\
(0,1489)\end{array}$ & $\begin{array}{c}0,3149 \\
(0,3400)\end{array}$ \\
\hline Total Loans/Assets & $\begin{array}{l}-0,1312^{*} \\
(-1,7570)\end{array}$ & $\begin{array}{l}-0,2650^{* *} \\
(-2,1658)\end{array}$ & $\begin{array}{l}-0,5934^{* *} \\
(-2,1834)\end{array}$ & $\begin{array}{l}0,5272^{* * *} \\
(3,7755)\end{array}$ \\
\hline Total Capital/Assets & $\begin{array}{l}0,4594^{* * *} \\
(5,0359)\end{array}$ & $\begin{array}{c}-0,0574 \\
(-0,3965)\end{array}$ & $\begin{array}{c}0,6092^{*} \\
(1,7657)\end{array}$ & $\begin{array}{c}-0,1742 \\
(-1,0373)\end{array}$ \\
\hline Net Profit After Tax/Assets & $\begin{array}{c}0,0519 \\
(0,1361)\end{array}$ & $\begin{array}{c}-0,6491 \\
(-1,0692)\end{array}$ & $\begin{array}{c}-0,2516 \\
(-0,6629)\end{array}$ & $\begin{array}{c}0,0331 \\
(0,1703)\end{array}$ \\
\hline Liquid Asset/Assets & $\begin{array}{l}0,1517^{* * *} \\
(4,6237)\end{array}$ & $\begin{array}{c}0,0605 \\
(1,1631)\end{array}$ & $\begin{array}{c}-0,1447 \\
(-0,7870)\end{array}$ & $\begin{array}{c}0,0743 \\
(0,7853)\end{array}$ \\
\hline \multicolumn{5}{|l|}{ Bank Characteristics $_{t-1}$} \\
\hline Assets & $\begin{array}{c}0,0125 \\
(0,9196)\end{array}$ & $\begin{array}{l}-0,0466^{* *} \\
(-2,1160)\end{array}$ & $\begin{array}{c}0,0387 \\
(0,4551)\end{array}$ & $\begin{array}{l}-0,0968^{* *} \\
(-2,2714)\end{array}$ \\
\hline Deposits/Total Funding Base & $\begin{array}{l}-0,2478^{* * *} \\
(-4,1891)\end{array}$ & $\begin{array}{c}-0,0450 \\
(-0,4826)\end{array}$ & $\begin{array}{l}-0,9373^{* * *} \\
(-5,7370)\end{array}$ & $\begin{array}{l}-0,1906^{* *} \\
(-2,2840)\end{array}$ \\
\hline Operational Efficiency & $\begin{array}{l}0,1828^{* * *} \\
(2,9086)\end{array}$ & $\begin{array}{l}0,3331^{* * *} \\
(3,3044)\end{array}$ & $\begin{array}{c}-0,0057 \\
(-0,0574)\end{array}$ & $\begin{array}{c}0,0165 \\
(0,3244)\end{array}$ \\
\hline \multicolumn{5}{|l|}{ Dummy Variables } \\
\hline Foreign Banks $_{t-1}$ & $\begin{array}{l}-0,2088^{*} \\
(-1,7203)\end{array}$ & $\begin{array}{c}0,0883 \\
(0,4564)\end{array}$ & $\begin{array}{c}-0,1069 \\
(-0,4579)\end{array}$ & $\begin{array}{c}0,0142 \\
(0,1174)\end{array}$ \\
\hline State-controlled Banks $t_{t-1}$ & $\begin{array}{c}0,1368^{*} \\
(1,7320)\end{array}$ & $\begin{array}{l}-0,0215^{* *} \\
(-0,1705)\end{array}$ & & \\
\hline Partial Deposit Insurance & & & $\begin{array}{c}0,1023^{*} \\
(1,6563)\end{array}$ & $\begin{array}{l}-0,0871^{* * *} \\
(-2,7831)\end{array}$ \\
\hline \multicolumn{5}{|l|}{ Macroeconomy $y_{t-1}$} \\
\hline Change in Price Index & $\begin{array}{l}1,2238^{* *} \\
(2,3467)\end{array}$ & $\begin{array}{l}2,1595^{* * *} \\
(2,5905)\end{array}$ & $\begin{array}{c}-0,0951 \\
(-0,1420)\end{array}$ & $\begin{array}{c}-0,4482 \\
(-1,3056)\end{array}$ \\
\hline Change in FX Rate & $\begin{array}{c}-0,0837 \\
(-0,2391)\end{array}$ & $\begin{array}{c}-0,0450 \\
(-0,4826)\end{array}$ & & \\
\hline Adjusted R-Square & 0,0589 & 0,2916 & 0,1809 & 0,4080 \\
\hline F-Statistics & $61,24^{* * *}$ & $241,68^{* * *}$ & $14,93^{* * *}$ & $37,65^{* * *}$ \\
\hline Number of Banks & 366 & 366 & 41 & 41 \\
\hline
\end{tabular}


We find that both Russian and Turkish depositors prefer well capitalized banks. Depositors view an increase in capital as an indicator that lessens the chance of a bank becoming insolvent due to bad loans. We observe a stronger response by Turkish depositors to an increase in the capital ratio. The strong response of depositors in Turkey may be due to the increase in the foreign ownership in Turkish banks after 2001. While increasing capital is costly, after the depreciation of the domestic currency, Turkish bank shares became cheap for foreign investors. So, this created an opportunity for depositors to place the funds in the newly recapitalized banks as a safe haven.

Russian depositors react positively to increased liquidity. When banks reduce risky loans, they replace them with liquid assets which support Bernanke and Lown's (1991) view that a costly adjustment takes place when banks' asset risk increases. Liquidity is not significant consideration for Turkish depositors because, it is widely known that banks hold large amounts of government bonds that are highly liquid so the Turkish banks carried a relatively smaller share of risky loans in their portfolios compared to the Russian banks. The remaining two risk measures, namely the non-performing loans and profitability, do not have the expected impact on the growth of deposits. Since, banks try to keep the ratio of non-performing loans to loans more or less below a certain ratio, non-performing loans do not have an effect on deposits.

Price response by depositors to bank asset and capital risks are shown in columns (2) and (4) for each country. Implicit interest rates predictably decline in both the Russian Federation and Turkey when deposit growth accelerates. Interest rate increases on deposits are followed by higher interest rates in the following period. In theory, pricing of debt or equity contracts by the market participants reflects the risk of the issuer. So, one would expect all risk factors to be relevant. However, the only significant risk variable both in the Russian Federation and Turkey is the ratio of loans to assets. The ratio has the wrong sign in column (2) for the Russian banks. This is in part due to lack of existence of secondary markets to reduce exposure to high risk loans. Russian depositors are not able to demand higher interest rates on deposits when their banks increase the size of their loan portfolio relative to total assets. This may be attributable to the small size of deposits in the Russian banks. Thus, banks are able to keep their interest costs low despite increases in credit risk (see also [Ungan, Caner, Ozyildirim, 2008]). However, in Turkey the opposite is true. Column (4) includes the price response of Turkish depositors to bank risks. The interest rate response has the expected sign to increases in loans.

There is no significant relation or a correct sign in the Russian Federation by means of demanding higher interest rates for increased risk. In the Russian Federation, banks are able to dictate interest rates on depositors. However, a limited price risk relation exists in Turkey.

The possibility of bailing-out banks by regulatory agencies is referred to as a «too-big-tofail» (TBTF) policy. In general, a bank tends to become larger and riskier if uninsured depositors believe that they will benefit from TBTF coverage. In theory, for large banks the objective is either to maintain market share or improve efficiency. Therefore, one should not expect a significant relation between deposit growth and the size of banks except in times of crisis. Our results indicate that size is not a significant determinant of deposit flows. This may be due to the fact that both in the Russian Federation and in Turkey large state-owned banks are losing market share of deposits and are slated for privatization. Nevertheless, size is important in the determination of interest rates. Large banks in both countries were able to pay lower interest rates on deposits. Hence, there are still indications of the effect of TBTF protection.

More efficient banks in the Russian Federation have been able to increase their deposits while it is not a significant factor in Turkey. Russian banking industry improved efficiency with 
better management and control of operational costs as well as consolidations. Many poorly run banks were either closed or changed ownership since 2000. Better run banks, particularly, the so called diversified banks were able to attract more deposits while paying higher interest rates without giving up profitability. The sign of efficiency in column (2) is positive contrary to what is expected. However, the positive sign of efficiency may be due to the fact that efficient banks have the ability to pay higher interest rates while maintaining efficiency through better control of non-deposit inputs.

Ownership is significant in determining deposits flows and the interest rate on deposits. The signs of foreign and state ownership dummy are opposite and significant for the Russian banking industry. Depositors view state-ownership as safety and are willing to accept lower interest rates on deposits. However, foreign banks service a very small portion of the depositors and these depositors may not be representative of the overall depositor population. In Turkey, foreign ownership is not significant at all because, depositors do not see any reason to differentiate between foreign and domestic banks. The dummy variable for foreign banks indicates whether a bank is foreign-owned or not. It does not measure the effect of foreign ownership in domestic banks. So, it has the wrong sign in the deposit growth equation for the Russian Federation and is insignificant in other equations.

We did not include the deposit insurance dummy in estimations of the Russian banks because the insurance became effective only in the last year of the sample period. However, the effect of deposit insurance was as expected in Turkey. One year after the crisis, interest rates started to decline in Turkey. Introduction of limited deposit insurance corresponds with declining interest rates. Therefore, the negative sign of the limited deposit insurance coefficient in the interest rate equation indicates a time effect rather than the effect of a reduction in deposit insurance.

Overall, depositor's response to bank risk taking is significant. Depositors expect banks to increase capital when faced with economic conditions that increase the asset risks. While reduction of loans is also significant, depositors are not willing to give up bank interest income in order to reduce risky loans.

\section{Conclusion}

Depositor's monitoring of banks serves as an important tool for limiting risk taking by banks thus avoiding large bank losses as experienced in the Russian Federation in 1998 and Turkey in 2001. Russian banking industry and households has been experiencing major changes in financial intermediation as the economy transforms into a market-based economy. Similar developments in banking are also taking place elsewhere around the world. In the Russian Federation, depositors suffered large losses after the crisis in 1998 while in Turkey depositors as well as other creditors were fully protected from incurring any losses during the banking crisis in 2001. So, do we observe differences in the behavior of depositors after such an experience?

Depositors do one or a combination of two things when faced with excessive risk taking by banks. They withdraw their funds placed in the banks or demand higher interest rates when the banks' risk factor increases. We do see evidence of depositors' withdrawal of funds both in the Russian Federation and in Turkey in response to higher asset risks. In addition, another significant factor that determines the change in the flow of deposits is the capital adequacy of banks which 
is true both in the Russian Federation and Turkey. Depositors consider capital ratio as a sufficient statistic for assessing a bank's riskiness. Depositors observe changes in the economic conditions and conclude that banks that can to increase capital, no matter how much it costs, are safer than others.

Liquidity is also an important factor in determining the deposits held in banks. But, here the depositors demonstrate different behavior in the Russian Federation than the depositors in Turkey. While depositors increase funds in liquid banks in the Russian Federation, liquidity is not perceived as an indicator of low risk in Turkey, because banks may be funding liquid assets with international funds which increase exchange rate risk. In addition, Turkish banks carry a large amount of government bonds as share of their assets.

We do not find any evidence of risk-return relationship on banks in the Russian Federation. This may be attributable to the overall small size of deposits available to banks. Also, Russian banking industry includes a significant share of intra-group banks related to major corporations where the parent company and affiliates are the major depositors. In Turkey, limited price changes are observed in banks that increase the share of loan portfolio in assets.

Depositor's reaction both in the Russian Federation and in Turkey is influenced by non-risk factors as well. Market development, effectiveness of supervisory agencies, types of banks and types of depositors all affect depositors' influence on banks. For example, in the Russian Federation, depositors still remember the effects of loss of wealth in the early 1990s due to hyper inflation and the 1998 crisis. They are cautious in placing savings in the banking system. In Turkey banks operate in a more level field but the guarantees provided by the bank supervisors reduce the role of market forces in limiting bank risk-taking behavior. In the Russian Federation, the dominance of state-owned banks provides an implicit protection. So, deposits tend to concentrate in state-owned banks. However, this tendency is changing due to the ability of the efficient private banks in increasing their market share of total deposits.

The existence of depositor's reaction against risk in the Russian Federation is encouraging in terms of controlling risk-taking behavior of banks. However, one should not ignore the role of CBR in improving the fundamentals in the banking industry. CBR has introduced stringent regulations in terms of accounting standards, and new norms on capital adequacy, liquidity and foreign exchange risks as well as limits on related party lending since 2001. Similar changes have also occurred in Turkey since the establishment of the Bank Regulatory and Supervisory Agency in 2000. The weak supervision exercised initially was replaced by improved supervision supported by a new banking law which limits related party lending and concentration of loan risks. Strict reporting requirements and frequent bank examinations by the Agency as well as independent examiners resulted in improved fundamentals and limited excessive risk-taking. Despite these improvements, in the case of the Russian Federation, the extent of monitoring by bank supervisors differs by region.

However, there is still much to be learned about the changes in the Russian and Turkish banking industry. For example, further analysis is needed on regional banks in the Russian Federation as well as the competition between intra-group banks and diversified independent banks which have demonstrated significant growth in the past several years. Diversified banks deserve special attention since they may be instrumental in improving financial intermediation in the Russian Federation. Finally, both the Russian Federation and Turkey are experiencing increased share of foreign banks. The effects of foreign bank participation on depositor behavior would be a further area of research in both countries. 


\section{References}

Banking Regulation and Supervision Agency of Turkey (BDDK) (2010) From Crisis to Financial Stability (Turkey Experience). Banking Regulation and Supervision Agency Working Paper, September. Barajas A., Steiner R. (2000) Depositor Behavior and Market Discipline in Colombia. IMF Working Paper, WP/00/214.

Bernanke B., Lown C. (1991) The Credit Crunch. Brookings Papers on Economic Activity 2, pp. 205-248. Birchler U.W., Maechler A.M. (2002) Do Depositors Discipline Swiss Banks? Prompt Corrective Action in Banking: 10 Years Later (ed. G.G. Kaufman), New York: Elsevier Science, pp. 243-275.

Bredenkamp H., Josefsson M., Lindgren C.-J. (2009) Turkeys Renaissance: From Banking Crisis to Economic. Successes of the International Monetary Fund (eds. E. Brau, I. McDonald), New York: Palgrave Macmillan, pp. 64-84.

Calomiris C.W., Powell A. (2001) Can Emerging Market Bank Regulators Establish Credible Discipline? The Case of Argentina, 1992-1999. Prudential Supervision: What Works and What Doesn't (ed. F.S. Mishkin), National Bureau of Economic Research, Inc., pp. 147-196.

Caprio G., Honohan P. (2005) Can the Unsophisticated Market Provide Discipline? World Bank

Policy Research Working Paper no 3364.

Central Bank of Russian Federation (CBR) (2010) Statistical Bulletin 2010, Moscow.

Central Bank of Russian Federation (CBR) (2006) Banking Supervision Report 2005, Moscow.

Central Bank of Russian Federation (CBR) (2005) Banking Supervision Report 2004, Moscow.

Davies S., Robitaille P. (1997) Market Discipline and Bank Certificates of Deposit: Evidence from Chile.

Board of Governors of the Federal Reserve System (unpublished).

D'Amato L., Grubisic E., Powell A. (1997) Contagion, Bank Fundamentals or Macroeconomic Shock?

An Empirical Analysis of the Argentine 1995 Banking Problems. Working Paper no 2, Central Bank of Argentina, July, www.bcra.gov.ar.

Dinger V. (2009) Do Foreign-owned Banks Affect Banking System Liquidity Risk? Journal of Comparative Economics, no 37, pp. 647-657.

Deposit Insurance Agency of the Russian Federation (2009) Annual Report.

Goldberg L., Hudgins S. (1996) Response of Uninsured Depositors to Impending S\&L Failures:

Evidence of Depositor Discipline. Quarterly Review of Economics and Finance, no 36, pp. 311-325.

Kaufman G.G. (2010) The Financial Turmoil of 2007-2009: Sinners and their Sins. Networks Financial Institute Policy Brief no 2010-PB-01.

Maechler A., McDill K. (2006) Dynamic Depositor Discipline in US Banks. Journal of Banking and Finance, no 30, pp. 1871-1898.

Martinez Peria M.S., Schmukler S.L. (2001) Do Depositors Punish Banks for Bad Behavior? Market

Discipline, Deposit Insurance and Banking Crises. The Journal of Finance, no 56, pp. 497-514.

Mondschean T.S., Opiela T.P. (1999) Bank Time Deposit Rates and Market Discipline in Poland:

The Impact of State Ownership and Deposit Insurance Reform. Journal of Financial Services Research, no 15 , pp. 179-196.

Opiela T.P. (2004) Was There an Implicit Full Guarantee at Financial Institutions in Thailand?:

Evidence of Risk Pricing by Depositors. Journal of Comparative Economics, no 32, pp. 519-541.

Park S., Peristiani S. (1998) Market Discipline by Thrift Depositors. Journal of Money, Credit, and Banking, no 30, pp. 347-365.

Turbanov A. (2010) Statement by the Head of Deposit Insurance Agency, May 21, www.asv.org.ru/agency/ appearance/show/?id=167929.

Ungan E., Caner S., Ozyildirim S. (2008) Depositors' Assessment of Bank Riskiness in the Russian Federation. Journal of Financial Services Research, no 33, pp. 77-100. 